\title{
NUTRITION-RELATED DISEASES IN THE MEDICINES REIMBURSEMENT SYSTEM OF LATVIA
}

\author{
Diāna Arāja \\ Faculty of Economics and Management, University of Latvia, Aspazijas bulv. 5, Rīga LV-1050, LATVIA; \\ Diana.Araja@apollo.Iv
}

Communicated by Ingrīda Rumba

\begin{abstract}
In Latvia, the medicine reimbursement system for outpatient treatment operates under conditions of limited resources, and the state budget financing has been reduced in recent years. Under such circumstances, a necessity to identify additional possibilities to optimise resources allocation to health care programmes and prevention activities is important. The aim of this research was to identify nutrition-related diagnoses in the Latvian medicine reimbursement system and to determine potential efficiency of the resource allocation to complementary nutrition programmes. To meet the aim defined, theoretical research methods (analysis of legislative documents and special literature analysis) were used alongside empirical research methods (data collection: documentary analysis, statistical database analysis). The results of this research showed that the largest amount of reimbursed diagnoses, such as cardiovascular diseases, diabetes, cancer, digestive diseases, and osteoporosis, are identified as nutrition-related diagnoses in the review of special literature. Determination of the efficiency of complementary nutrition programmes is a crucial issue in the context of the evidence-based medicine, both in terms of direct and indirect costs to society and government, and in terms of disability-adjusted life years and other health determinants directly related to patients. For this reason, possibilities for the evaluation of relative efficiency of the nutrition programmes for reimbursed diagnoses are investigated in depth.
\end{abstract}

Key words: health care, allocation of resources, allocative and technical efficiency.

\section{INTRODUCTION}

The Latvian medicine reimbursement system for outpatient treatment has developed starting from the 1990s. The 2006 Regulations No. 899 of the Cabinet of Ministers of the Republic of Latvia, "Procedures for the Reimbursement of Expenditures for the Acquisition of Medicinal Products and Medicinal Devices Intended for Out-patient Medical Treatment" (hereafter - Regulations No. 899), regulate this system at the present. The procedures for reimbursement are a set of measures that provide patients with an opportunity to acquire medicinal products and medical devices, the expenditures for the acquisition of which are completely or partially covered by funds from the state budget for the current year, granted for the reimbursement of expenditures for the acquisition of medicinal products in accordance with these regulations, or by the funds granted in accordance with the Social Security Network Strategy (Anonymous, 2006).

Nineteen groups of diagnoses are reimbursed in accordance with the Regulations No. 899 (groups of diagnoses are classified by the International Statistical Classification of Diseases and Relates Health Problems $10^{\text {th }}$ Revision (ICD-10)). Expenditures for the reimbursement of medicinal products are covered under the following reimbursement categories (Anonymous, 2006):

- Category I - reimbursement in the amount of $100 \%$, if it has been determined that a patient has a chronic, lifethreatening disease or a disease, which causes serious irreversible disability and the medical treatment of which requires the use of the respective medicinal products in order to maintain the patient's vital functions;

- Category II - reimbursement in the amount of $75 \%$, if it has been determined that a patient has a chronic disease, in the medical treatment of which the maintenance of the patient's vital functions is made difficult or which causes serious disability without the use of the respective medicinal products; and

- Category III - reimbursement in the amount of 50\%, if it has been determined that a patient has a chronic or acute disease, in the medical treatment of which the use of the respective medicinal products is necessary in order to maintain or improve the patient's state of health or in the case where vaccines are paid for from the funds granted for reimbursement. 


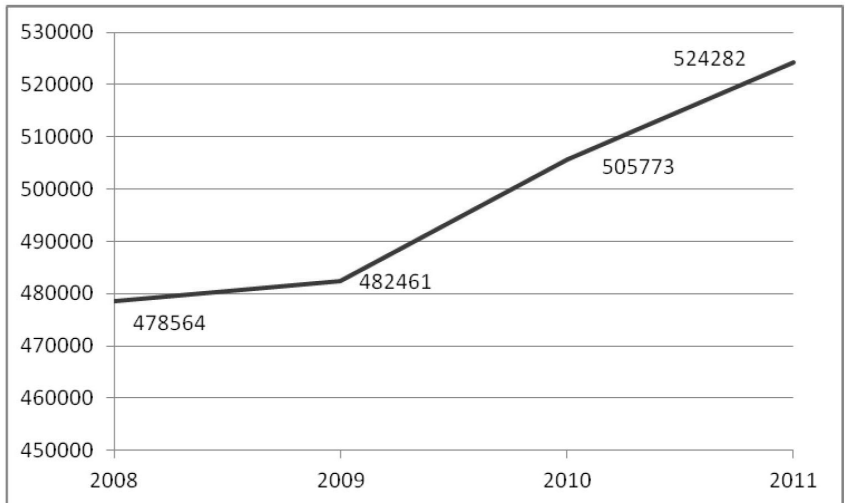

Fig. 1. Number of patients treated in the reimbursement system for outpatient treatment in Latvia, 2008-2011 (Anonymous, 2012).

The number of patients treated through the reimbursement system has increased yearly (Fig. 1). The biggest number of patients is treated through the reimbursement system in the group of diagnoses "Diseases of the circulatory system", "Endocrine, nutritional and metabolic diseases" and "Diseases of the respiratory system", and the number of patients ioural disorders" in which the number of patients has declined in 2011) (Fig. 2).

In spite of a relatively low number of patients with diseases of the digestive system, this group is one of the more important in mortality data (Table 1). Table 1 includes data of mortality in Latvia and in neighbouring Baltic States.

The largest part of the health care budget resourses for the reimbursement system is allocated for diseases of the circulatory system, endocrine, nutritional und metabolic diseases and neoplasms (Fig. 3). However, the data on total expenditure for reimbursed medicinal products (budget allocation and patients' co-payment) show that the patients' copayment has increased in circumstances of reduced budget is rising annually (excluded diagnoses "Mental and behav-

DEATHS BY CAUSE PER 100000 POPULATION IN ESTONIA, LATVIA AND LITHUANIA BY MAJOR GROUPS OF CAUSES (Anonymous, 2010)

\begin{tabular}{|c|c|c|c|}
\hline \multirow[t]{2}{*}{ Cause of death } & \multicolumn{3}{|c|}{$\begin{array}{l}\text { Deaths by cause per } 100000 \\
\text { population in Baltic States }\end{array}$} \\
\hline & Estonia & Latvia & Lithuania \\
\hline Diseases of the circulatory system & 652.9 & 727.1 & 718.8 \\
\hline Neoplasms & 269.0 & 273.6 & 251.2 \\
\hline $\begin{array}{l}\text { Injury, poisoning and certain other } \\
\text { consequences of external causes }\end{array}$ & 84.7 & 94.1 & 123.1 \\
\hline $\begin{array}{l}\text { Symptoms, signs and abnormal clinical } \\
\text { and laboratory findings, not elsewhere } \\
\text { classified }\end{array}$ & 23.7 & 85.0 & 16.7 \\
\hline Diseases of the digestive system & 45.9 & 46.7 & 67.5 \\
\hline Diseases of the respiratory system & 31.7 & 29.6 & 38.9 \\
\hline
\end{tabular}

allocation, as the need for treatment, based on growing patients number, increases independently of budget resources allocated (Fig. 4). In these circumstances, taking into account the limited state budget for the medicine reimbursement system and patient resources, the aim of this research was to identify additional possibilities to optimise resource allocation to the health care, based on nutrition-related diagnoses in the medicine reimbursement system and potential efficiency of complementary nutrition programmes.

\section{MATERIALS AND METHODS}

To meet the aim defined, theoretical research methods (analysis of legislation, special literature analysis and analysis of electronic resources) were used alongside empirical research methods (data collection: document analysis, statistical database analysis). For data processing and analysis, statistical analysis methods (comparison, grouping, calculation of averages) and methods of economic analysis were used.

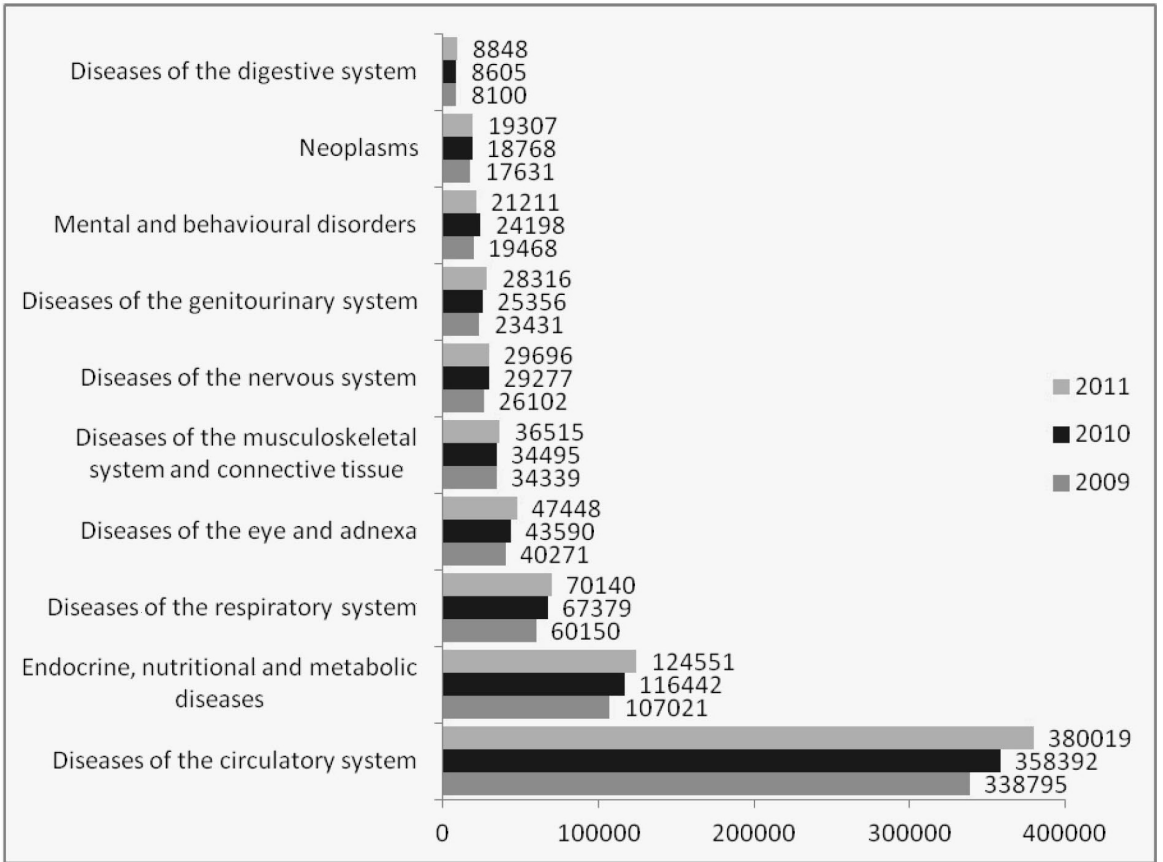

Fig. 2. Number of patients treated in the reimbursement system for outpatient treatment by the ten biggest diagnoses groups in Latvia, 2009-2011 (Anonymous, 2012). 


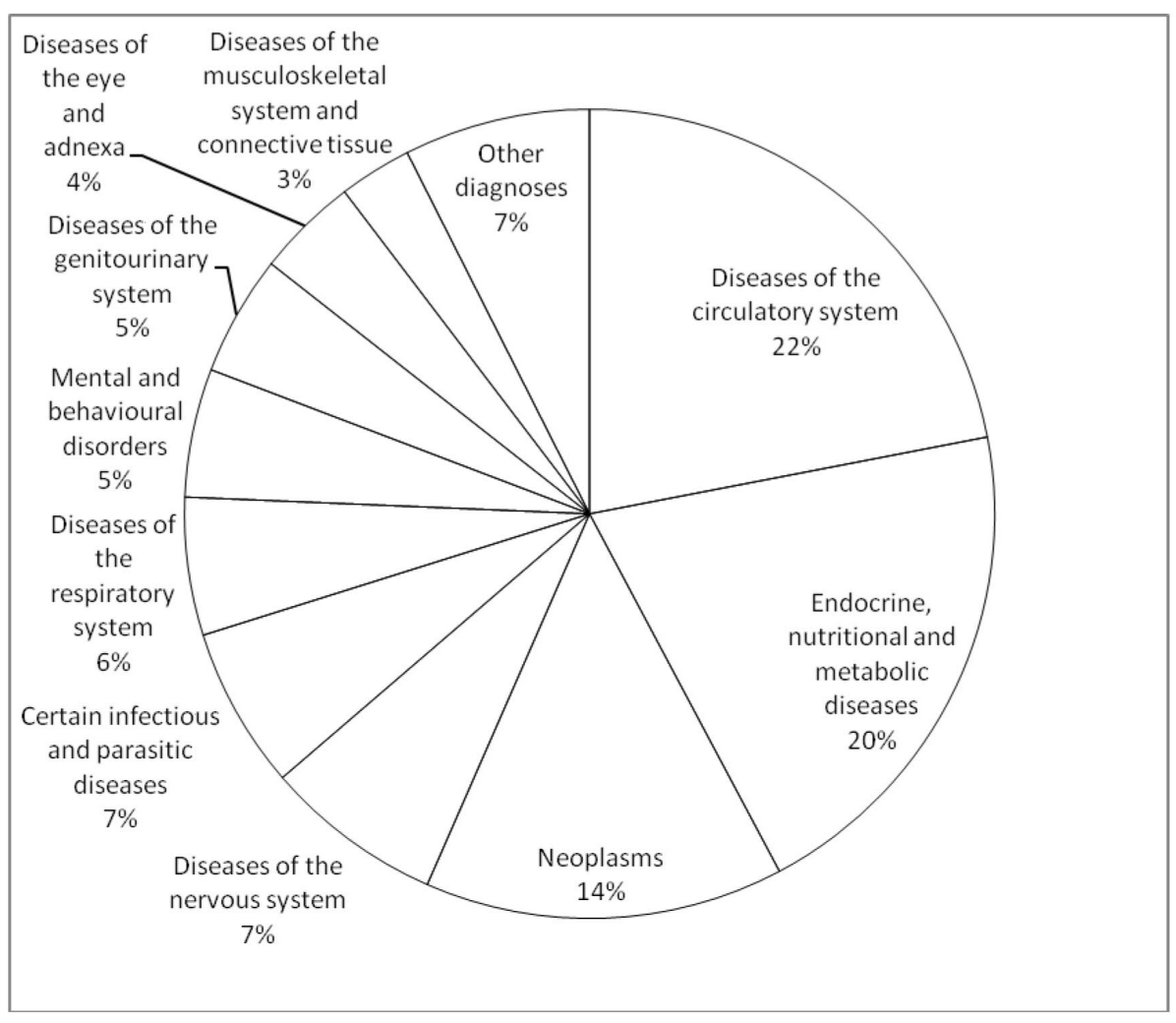

Fig. 3. Health care budget expenditure by groups of diagnoses in Latvia, 2011 (Anonymous, 2012).

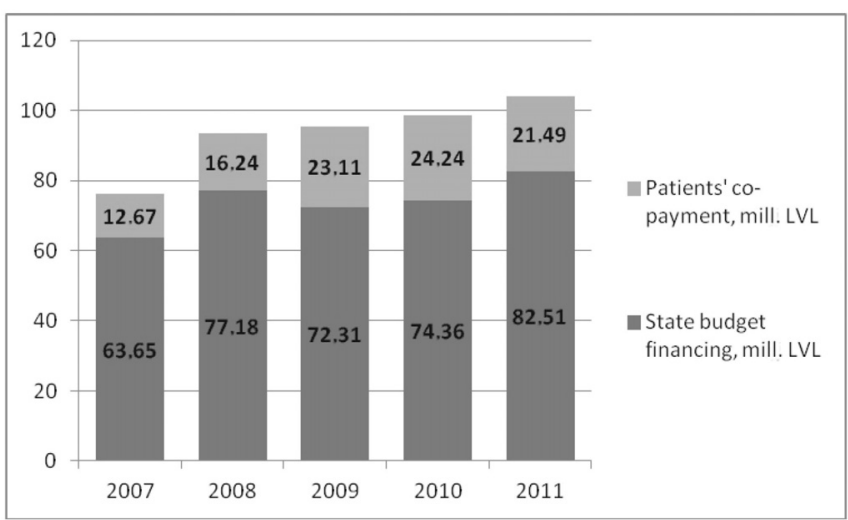

Fig. 4. State budget recourses allocated for the reimbursement system and patients' co-payment in Latvia, 2007-2011 (Anonymous, 2012).

\section{RESULTS}

The World Health Organisation in the Report of a Joint WHO/FAO Expert Consultation "Diet, Nutrition and the Prevention of Chronic Diseases", 2003, indicated that chronic diseases are largely preventable diseases. Although more basic research may be needed on some aspects of the mechanisms that link diet to health, the available scientific evidence provides a sufficiently strong and plausible role of prevention. Beyond the appropriate medical treatment for those already affected, the public health approach of primary prevention is considered to be the most cost-effective, affordable and sustainable course of action to cope with the chronic disease epidemic worldwide. The above mentioned report reviewed the evidence on the effects of diet and nutrition on chronic diseases and made recommendations for public health policies and strategies that encompass socie- tal, behavioural and ecological dimensions. In setting out ways to decrease the burden of chronic diseases (such as obesity, type 2 diabetes, cardiovascular diseases (including hypertension and stroke), cancer, dental diseases and osteoporosis), the report proposed that nutrition should be placed at the forefront of public health policies and programmes.

In the present study, a literature review provided sufficient evidence that the largest part of the reimbursed diagnoses in Latvia are nutrition-related diseases (in the following list the directly nutrition-related diagnoses are marked in bold and the indirectly nutrition-related diagnoses in italic):

\section{Specific infectious and parasitic diseases}

\section{Neoplasms}

III. Diseases of the blood and blood-forming organs and certain disorders involving the immune mechanism

IV. Endocrine, nutritional and metabolic diseases

V. Mental and behavioural disorders

VI. Diseases of the nervous system

VII. Diseases of the eye and adnexa

VIII. Diseases of the ear and mastoid process

\section{Diseases of the circulatory system}

X. Diseases of the respiratory system

\section{Diseases of the digestive system}

XII. Diseases of the skin and subcutaneous tissue 
XIII. Diseases of the musculoskeletal system and connective tissue

\section{Diseases of the genitourinary system}

\section{Pregnancy, childbirth and the puerperium}

\section{Specific conditions originating in the perinatal} period

XVII. Congenital malformations, deformations and chromosomal abnormalities XVIII. Injury, poisoning and certain other consequences of
external causes

\section{Factors influencing health status and contact with health services}

The diagnosis of diabetes mellitus, as an example, justifies the approach of the direct and indirect relation with nutrition.

There are two main types of diabetes mellitus:

- Type 1 diabetes (T1DM) usually develops in childhood and adolescence and patients require lifelong insulin injections for survival;

- Type 2 diabetes (T2DM) usually develops in adulthood and is related to obesity, lack of physical activity, and unhealthy diets. This is the more common type of diabetes (representing 90\% of diabetic cases worldwide (Diabetes Programme, WHO, 2012), as well as in Latvia (Anonymous, 2012g) and treatment may involve lifestyle changes and weight loss alone, or oral medications or even insulin injections.

In Latvia the direct treatment of type 2 diabetes patients (more than 70000 patients) consumes almost 15\% of the overall state budget for the reimbursement system (Anonymous, 2012g). At the same time, diabetes mellitus causes a lot of complications, such as following (Anonymous, 2012a):

- Diabetes mellitus increases the risk of heart disease and stroke $-50 \%$ of people with diabetes die of cardiovascular disease (primarily heart disease and stroke).
- Combined with reduced blood flow, neuropathy in the feet increases the chance of foot ulcers and eventual limb amputation.

- Diabetic retinopathy is an important cause of blindness, and occurs as a result of long-term accumulated damage to the small blood vessels in the retina. After 15 years of diabetes, approximately $2 \%$ of people become blind, and about $10 \%$ develop severe visual impairment.

- Diabetes mellitus is among the leading causes of kidney failure - 10-20\% of people with diabetes die of kidney failure.

- Diabetic neuropathy is damage to the nerves as a result of diabetes, and affects up to $50 \%$ of people with diabetes mellitus. Although many different problems can occur as a result of diabetic neuropathy, common symptoms are tingling, pain, numbness, or weakness in the feet and hands.

- The overall risk of dying among people with diabetes mellitus is at least double the risk of their peers without diabetes mellitus.

In 2011, the treatment of diabetes mellitus complications was ensured for 53400 patients, there were 314 direct disability cases and 486 deaths caused by diabetes in Latvia (Anonymous, 2012g). In the author's opinion, the calculation of the Potential Years of Life Lost (PYLL) and Disability-Adjusted Life Years (DALY) are the most appropriate methods to evaluate the economic impact of this disease, but for this purpose, data of mortality by age and gender should be used, which are not available on the statistic database websites.

Data on morbidity by groups of age and gender show that under age of 50 years the diabetes mellitus prevalence is higher for males, but beginning from 50 years the morbidity sufficiently increases with higher prevalence for females. The number of patients is particularly high in the 7080-year age group of (Anonymous, 2012b). According to provisional results of the Central Statistic Bureau, the average life expectancy of inhabitants will rise (Anonymous, 2012b), and taking into account the population age structure (Fig. 5), an increase in the number of patients needed to

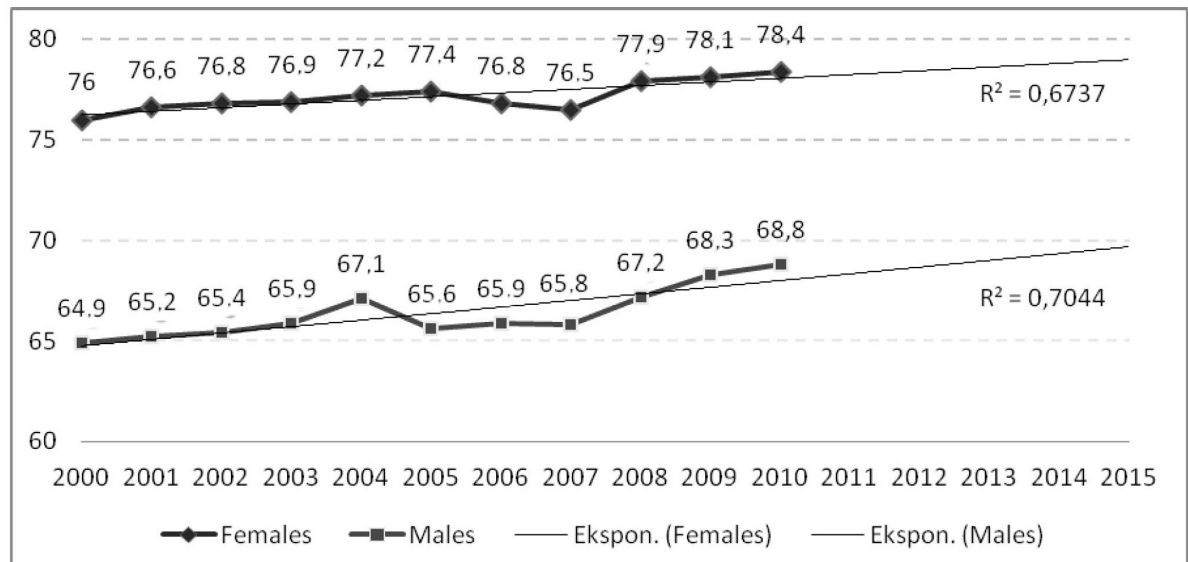

Fig. 5. Life expectancy at birth in Latvia, 2000-2010, and forecasts (Anonymous, 2011). 
treat is forecast not only for diabetes mellitus, but also for the other chronic diseases.

In these circumstances the search and assessment of alternative treatments, based on prevention, become important.

\section{DISCUSSION}

The author, by analysis of the medicine reimbursement system from allocative and technical efficiency points of view, notes that there has been a trend towards technical efficiency, rather than overall economic efficiency (Fig. 6). Figure 6 is based on the classic framework of the Farrell model, which makes it possible to decompose overall efficiency into technical and allocative efficiency. The output of the model is the treated patient, which is the outcome of two input variables (medicines, alternatives). Under the assumption that the production function is linearly homogeneous, the efficient unit isoquant shows all technically efficient combinations. In circumstances of a limited budget, represented by isocost line A1A2, the reimbursement result point is located at point $\mathrm{S}$ on line A1A2, which insures allocative efficiency, but not technical and overall efficiency, and therefore the patient does not receive complete treatment. There is a tendency to attempt to achieve technical efficiency at point $\mathrm{R}$ by increasing the budget assignation for medicine reimbursement (isocost line B1B2), but the treatment alternatives (nutrition programme, physician's time by consultation or manual therapy etc.) are not evaluated sufficiently. It should be taken into into account that the overall economic efficiency would be achieved by the evaluation and wider use of the alternatives (point $\mathrm{Q}$ on line A1A2). Any point on the isoquant line has technical efficiency, but only $\mathrm{Q}$ receives technical efficiency at minimum cost, by combination with allocative efficiency, to achieve the overall efficiency - the product of technical and allocative efficiency.

In the author's view, at least for individual reimbursement in the case when standard medicine therapy does not achieve the desired therapeutic effect, both the relative effectiveness of comparable medicines and other health technology assessment should be considered. In accordance with the International Society for Pharmacoeconomics and

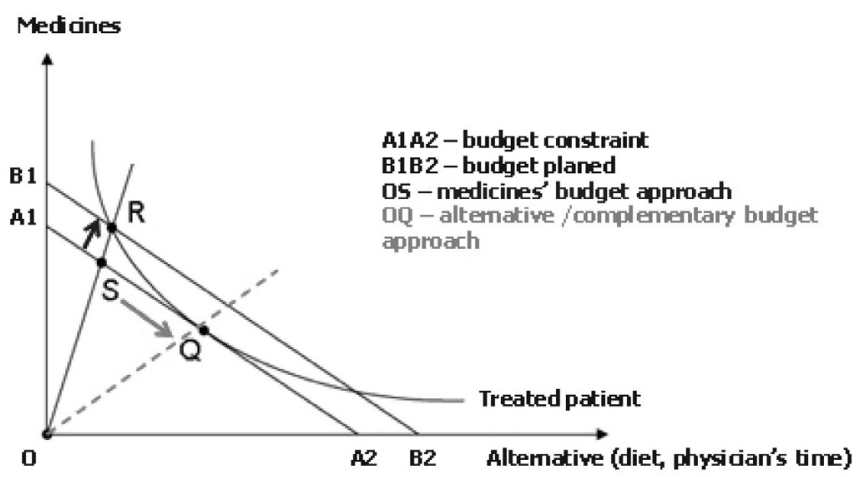

Fig. 6. Allocative, technical and overall efficiency in health care (Anonymous, 2008).
Outcomes Research, the goal of health technology assessment (HTA) is to provide policymakers with information on policy alternatives. Health care technology within the concept of HTA is defined broadly as consisting of medicines, biologicals, devices, equipment, supplies, medical and surgical procedures, support systems, organisational, delivery and managerial systems (Anonymous, 2003). For example, in the United Kingdom, competent authorities carry out complex HTA, which includes medicines, medical devices, vaccinations, screening programmes, medical staff services, procedures and public health programmes (Garrido et al., 2008). In Latvia, the evaluation of the economic efficiency is centered on assessment of medicines and medical devices, but there is not a competent authority for evaluation of the comparative efficiency of all applicable health technologies.

The essential role of the alternatives, for example, in the case of above mentioned type 2 diabetes, is justified by several randomised controlled trials (RCT), which show that lifestyle interventions based on diet and exercises, reduce the proportion of people with glucose tolerance that would otherwise develop T2DM. The results of RCT collected and evaluated in an academic dissertation on Assessment of Risk and Prevention of Type 2 Diabetes in Primary Health Care (Saaristo, 2011) showed that the 1-6 years incidence of diabetes was reduced in lifestyle trials by $30-60 \%$ compared with a control group. At the same time, the preventable use of Metforminum without lifestyle interventions showed less than $30 \%$ relative risk reduction of T2DM. Follow-up studies of the major lifestyle trials in prevention of type 2 diabetes in seven-year period showed a relative risk reduction of T2DM by 34-43\%, compared to the control group. Thus, these trials showed that T2DM can be prevented or delayed by lifestyle interventions. In scope of above mentioned academic dissertation, the effect of lifestyle interventions on weight and its association with glucose tolerance was evaluated in individuals at high risk for diabetes in a one-year follow-up. In total $17.5 \%$ of them lost more than $5 \%$ of weight. Their relative risk for diabetes decreased $69 \%$ compared with the group that maintained their weight (Saaristo, 2011).

Coming back to the issue of the limited budget and patient resources for the medicines reimbursement system, in the author's opinion a discussable question is also, data from the Central Statistical Bureau of Latvia that shows, based on the composition and structure of average consumption expenditure per household member, one third of the income of Latvian inhabitants is spent for food (Anonymous, 2012e). Thus, the rational diet is both the potential for disease prevention and saving resources for a healthy lifestyle.

The main conclusions of this research are following:

- The largest number of reimbursed diagnoses, such as cardiovascular diseases, diabetes, cancer, digestive diseases, osteoporosis, are identified as nutrient-related diagnoses by a special literature review. 
- The nutrient-related diagnoses contribute more than half of the state budget resources allocated to the reimbursement system in Latvia.

- The budget approach could be changed from medicinebased to an alternatives-based approach.

- There are not sufficient data to calculate indicators such as Potential Years of Life Lost (PYLL) and Disability-Adjusted Life Years (DALY), which can be used in economic assessment of treatment and preventive programmes.

- Prevention programmes for potential patients and educational programmes for patients should be encouraged.

- Data on composition and structure of consumption expenditure average per household member show that one-third of income is spent for food, and thus the Hippocrates' quote "Let food be thy medicine and medicine be thy food" can be important and useful also in the present epoch.

\section{REFERENCES}

Anonymous (2003). Diet, Nutrition and the Prevention of Chronic Diseases. WHO Technical Report Series 916, Report of a Joint World Health Organization. Food and Agriculture Organization of the United Nations Expert Consultation. Geneva: World Health Organization. http://www.fao.org/docrep/005/AC911E/AC911E00.HTM

Anonymous (2006). Procedures for the Reimbursement of Expenditures for the Acquisition of Medicinal Products and Medicinal Devices Intended for Out-patient Medical Treatment. Regulations No. 899 of the Cabinet of Ministers of the Republic of Latvia (adopted 31 October 2006, with amendments). http://www.likumi.lv/doc.php?id=147522

Anonymous (2008). Health Care Efficiency Measures: Identification, Categorization, and Evaluation. The Agency for Healthcare Research and Quality of the U.S. Department of Health \& Human Services. http://www.ahrq.gov/qual/efficiency/

Anonymous (2011). Composition and structure of consumption expenditure average per household member per month, 2010. Central Statistical Bureau of Latvia.

http://www.csb.gov.lv/en/composition-and-structure-consumption-expen diture-average-household-member-month
Anonymous (2011). Changes of demographic situation in Latvia in 2010. Central Statistical Bureau of Latvia.

http://www.csb.gov.lv/en/notikumi/changes-demographic-situation-latvia -2010-31979.html

Anonymous (2012a). Diabetes Programme. World Health Organization. http://www.who.int/diabetes/en/

Anonymous (2012b). Cukura diabēts (Statistikas dati par pacientu skaitu sadalījumā pa reǵioniem, vecuma grupām, dzimuma, cukura diabēta tipa, terapijas veida, diabēta komplikācijām, klīnisko izmeklējumu rezultātiem no 2007. gada līdz 2011. gadam) [Diabetes Mellitus (Statistical data on patients' number, allocation by regions, age groups, gender, type of Diabetes Mellitus, treatment methods, complications, results of clinical investigation, 2007-2011)]. Centre for Disease Prevention and Control of Latvia (in Latvian). http://www.spkc.gov.lv/veselibas-aprupes-statistika/

Anonymous (2012c). Health in the Baltic Countries, 2010 (19 $9^{\text {th }}$ edition). National Institute for Health Development of Estonia, the National Health Service of Latvia, Health Information Center of Lithuania.

http://www.spkc.gov.lv/veselibas-aprupes-statistika/

Anonymous (2012d). Invaliditāte [Statistical data on disability]. Centre for Disease Prevention and Control of Latvia (in Latvian).

http://www.spkc.gov.lv/veselibas-aprupes-statistika/

Anonymous (2012e). Population Census 2011 - Key Indicators. Central Statistical Bureau of Latvia.

http://www.csb.gov.lv/en/statistikas-temas/population-census-2011-keyindicators-33613.html

Anonymous (2012f). Statistikas dati par iedzìvotāju mirstību [Statistical data on population mortality]. Centre for Disease Prevention and Control of Latvia (in Latvian).

http://www.spkc.gov.lv/veselibas-aprupes-statistika/

Anonymous (2012g). Unpublished data of the National Health Service of Latvia on the medicines reimbursement system.

Berger, M. L., Bingefors, K., Hedblom, E. C., Pashos, C. L., Torrance, G. W. (2003). ISPOR Book of Terms. Health care cost, quality, and outcomes. Health Technology Assessment (pp. 133-134). International Society for Pharmacoeconomics and Outcomes Research. USA: ISPOR Press

Garrido, M. V., Zentner, A., Busse, R. (2008). Health technology assessment and health policy-making in Europe: Current status, challenges and potential. In: Health Systems, Health Policy and Health Technology Assessment (pp. 68-70). Copenhagen: WHO Regional Office for Europe.

Saaristo, T. (2011). Assessment of Risk and Prevention of Type 2 Diabetes in Primary Health Care. Academic dissertation, University of Oulu, Finland. http://herkules.oulu.fi/isbn9789514297113/isbn9789514297113.pdf

Received 1 October 2012

\section{UZTURA ATKARĪGĀS SLIMĪBAS ZĀḶU KOMPENSĀCIJAS SISTĒMA LATVIJĀ}

Latvijā ambulatorajai ārstēšanai paredzēto zāḷu un medicīnisko ierīču iegādes izdevumu kompensācijas sistēma darbojas stingri ierobežotu valsts budžeta līdzekḷu apstākḷos, līdz ar to aktuāls kḹūst jautājums par papildus iespēju izvērtēšanu līdzekḷu izlietojuma optimizācijai, ņemot vērā arī preventīvo pasākumu nozīmīgumu. Pētījuma mērkisis ir identificēt uztura atkarīgās slimības zāḷu iegādes izdevumu kompensācijas sistēmā un novērtēt iespējas noteikt papildinošo uztura programmu potenciālo efektivitāti. Mērka sasniegšanai izmantotas teorētiskās izpētes metodes (normatīvo dokumentu un speciālās literatūras analīze) un empīriskās izpētes metodes (statistikas datu vākšana, apkopošana un analīze). Pētījuma rezultāti liecina par to, ka lielākā dal̨a kompensējamo diagnožu, tādas kā sirds un asinsvadu slimības, diabēts, onkoloğiskās slimības, gremošanas sistēmas slimības, osteoporoze, ir uztura atkarīgās slimības, un tām tiek izlietota vairāk kā puse zāḷ kompensācijas sistēmai atvēlētā budžeta. Turklāt ir virkne slimību, kas ir netieši atkarīgas no uztura, bet tās rodas kā uztura atkarīgo slimību izraisītās komplikācijas. Uz pierādījumiem balstītās medicīnas laikmetā īpaši aktuāla kḷust ārstēšanas un preventīvo pasākumu ekonomiskās efektivitātes novērtēšana. Speciālajā literatūrā ir dati par uztura programmu pozitīvo nozīmi smagu slimību novēršanā vai ietekmes mazināšanā, tomēr jāatzīmēe, ka nav izstrādāta precīza metodolog̣ija, kas ḷautu veikt medikamentozās ārstēšanas un preventīvo pasākumu salīdzinošo ekonomiskās efektivitātes novērtěšanu, lai sagatavotu ar pierādījumiem pamatotu informāciju lēmumu pienemšanai par līdzekḷ sadali. Līidz ar to šis ir turpmākās izpētes objekts. 